\title{
Obituary for Andrew N. Porter (12 October 1945-4 March 2021)
}

Andrew N. Porter, who has died in Ludlow, Shropshire, England, aged 75, on 4 March 2021, was Rhodes Professor of Imperial History at King's College, University of London, from 1993 to his early retirement, owing to Parkinson's Disease, in 2008. Unusually for a historian working in a history department in a major research university, in the second half of his career he turned from his earlier work on South African and imperial economic history to develop a specialist interest in the history of the missionary movement, and in particular in British Protestant missions. More unusual still for a historian of imperialism, he set out to critique the accepted orthodoxy that missionaries were supporters of colonial agendas. Porter's groundbreaking and provocative book, Religion versus Empire? British Protestant Missionaries and Overseas Expansion 1700-1914 (Manchester University Press, 2004) was awarded the Reese Memorial Prize in 2006 for a wide-ranging scholarly work in the field of imperial and commonwealth history. Porter was the editor of The Oxford History of the British Empire, Vol. III: The Nineteenth Century (Oxford University Press, 1999), and also served as editor of the Journal of Imperial and Commonwealth History from 1979 to 1990, a journal which published two of his most important articles, assessing the impact of the Keswick holiness movement on British missions. He was actively involved in the Cambridge-based Currents in World Christianity Project (formerly the North Atlantic Missiology Project), funded by the Pew Charitable Trusts of Philadelphia, and edited one volume, The Imperial Horizons of British Protestant Missions, 1880-1914 (2003), in the resulting Eerdmans series, Studies in the History of Christian Missions. He was an extremely dedicated, meticulous, and successful supervisor of a number of $\mathrm{PhD}$ students whose work on different aspects of mission history has since gained global recognition, including Rhonda Semple, Steven Maughan, and John Stuart. Andrew was also an accomplished musician. He leaves a wife, Mary, sons Matthew and Simon, two grandsons, and a sister, Moira.

\section{Brian Stanley}

University of Edinburgh, Edinburgh, UK 